
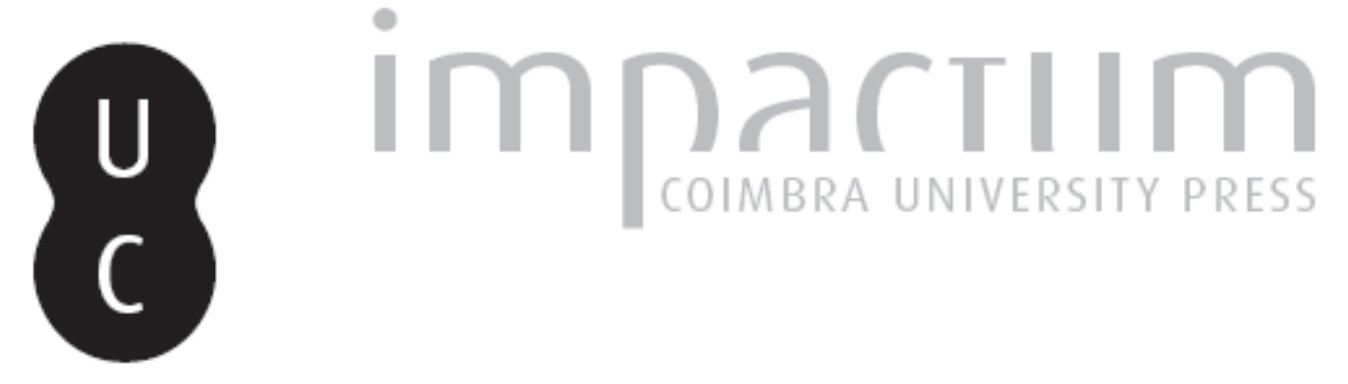

\title{
Acerca da liberdade de religião na Idade Média: mouros e judeus perante um problema teológico-canónico
}
Autor(es):
Antunes, José

Publicado por: Imprensa da Universidade de Coimbra

URL

persistente:

http://hdl.handle.net/10316.2/42910

DOI:

https://doi.org/10.14195/2183-8925_11_3

Accessed : $\quad$ 26-Apr-2023 11:41:42

A navegação consulta e descarregamento dos títulos inseridos nas Bibliotecas Digitais UC Digitalis, UC Pombalina e UC Impactum, pressupõem a aceitação plena e sem reservas dos Termos e Condições de Uso destas Bibliotecas Digitais, disponíveis em https://digitalis.uc.pt/pt-pt/termos.

Conforme exposto nos referidos Termos e Condições de Uso, o descarregamento de títulos de acesso restrito requer uma licença válida de autorização devendo o utilizador aceder ao(s) documento(s) a partir de um endereço de IP da instituição detentora da supramencionada licença.

Ao utilizador é apenas permitido o descarregamento para uso pessoal, pelo que o emprego do(s) título(s) descarregado(s) para outro fim, designadamente comercial, carece de autorização do respetivo autor ou editor da obra.

Na medida em que todas as obras da UC Digitalis se encontram protegidas pelo Código do Direito de Autor e Direitos Conexos e demais legislação aplicável, toda a cópia, parcial ou total, deste documento, nos casos em que é legalmente admitida, deverá conter ou fazer-se acompanhar por este aviso.

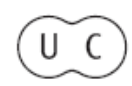


REVISTA DE HISTÓRIA DAS IDEIAS 11

\section{CULTURA POLÍTICA MENTALIDADES}

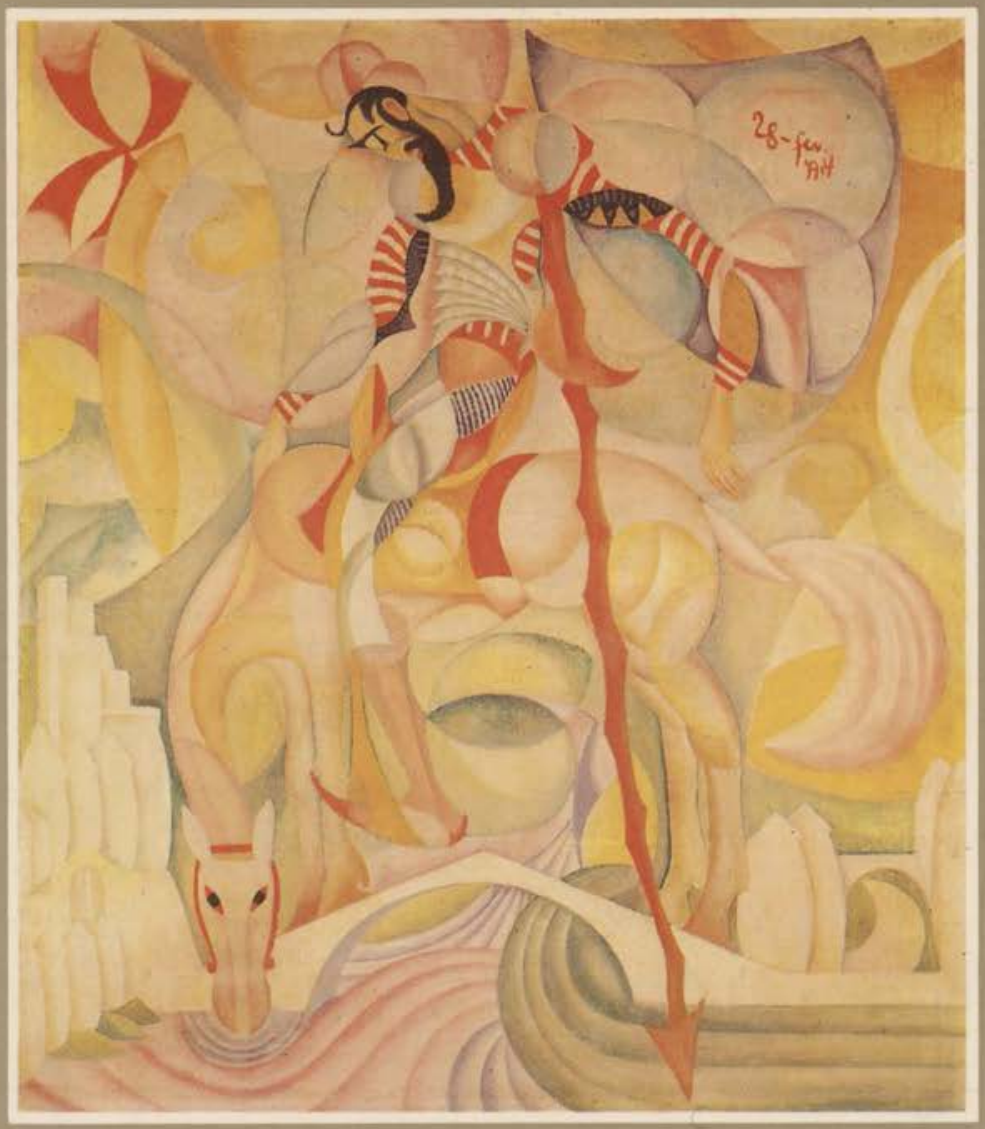

INSTITUTO DE HISTORIA E TEORIA DAS IDEIAS FACULDADE DE LETRAS 


\section{ACERCA DA LIBERDADE DE RELIGIÃO NA IDADE MÉDIA}

Mouros e Judeus perante um problema teológico-canónico

1. «Fica decretado, de futuro, ninguém pode ser obrigado a crer...., pois a salvação não tem que ser forçada, mas livre, para que se cumpra a justiça em toda a sua integridade».

Estas palavras, como porventura podem insinuar, estão longe de pertencer às sentidas expressões da Declaração Universal dos Direitos do Homem, de 10 de Dezembro de 1948, ou do Pacto Internacional dos Direitos Cívicos e Políticos, de 16 de Dezembro de 1966, ou até da Declaração dos Direitos da Criança, de 20 de Novembro de 1959, proclamados pela Assembleia Geral das Nações Unidas ( ${ }^{1}$ ). Foram pronunciadas no ano 633, no IV Concílio de Toledo, convocado pelo rei visigodo Sisenando $(\dagger 636)$ e presidido por Isidoro de Sevilha, na presença de $\mathbf{7 2}$ bispos das Espanhas e do Sul das Gálias. Precisamente contra o religiosíssimo príncipe Sisebuto (612-621), que levado por falso zelo, obrigava os judeus a receberem o baptismo $\left({ }^{2}\right)$.

* Faculdade de Letras da Universidade de Coimbra.

(1) Os artigos que se relacionam com a liberdade de consciência e de religião são, concretamente, os Art. os $18 .^{\circ}$ e $26 .^{\circ}$, n. 3 da Declaração Universal dos Direitos do Homem, o Art. $13 .^{\circ}$, n. 3 do Pacto Internacional de Direitos Económicos, Sociais e Culturais, os Art. $.^{\circ} 18 .^{\circ}$, n. 4 e 27. ${ }^{\circ}$ do Pacto Internacional de Direitos Cívicos e Políticos e os Princípios 1, 6 e 7 da Declaração dos Direitos da Criança. Sobre esta matéria cf. por exemplo, Jorge Miranda, Declaração Universal e os Pactos Internacionais de Direitos do Homem (Introdução e tradução de J. Miranda), Lisboa, 1977, 8, 11, 25, 48, 53 e Declaração dos Direitos da Criança, Lisboa, Ed. Logos, s.d.

$\left.{ }^{2}\right)$ O texto completo do canon V em referência (do qual oferecemos, em parte, uma tradução mais livre) é o seguinte: "Unde in concilio Toletano IV. c. 56. statutum est.

De judaeis autem praecipit sancta Synodus, nemini dei- 
Desde então transformou-se em lei, passou ao Decreto de Graciano, dist. 45, can. de Judaeis, mereceu ser defendido e interpretado por Tomás de Aquino e seguidamente reinterpretado e comentado por J. Dun's Escoto, servindo mais tarde de padrão, principalmente aos teólogos do século XVI, o século de ouro da Teologia, quando embrenhados nos novos problemas da época dos descobrimentos, se opuseram à aniquilação dos direitos dos índios, como à conquista das suas terras e à evangelização forçada desses mesmos povos nativos.

Os ecos profundos deste mesmo canon fizeram-se sentir igualmente em Portugal Medieval, sobretudo através da legislação de alguns dos nossos reis, com destaque para D. João I e D. Afonso V, que como bem atestam as Ordenações Afonsinas, contrariaram, e decididamente, o baptismo forçado, de quem quer que fosse, fossem eles mouros ou judeus $\left(^{(}\right)$.

Porém, não pensava, assim, totalmente, Martín Pérez, autor medieval do Libro de las Confessiones, obra escrita em

nceps ad credendum vim inferri. Cui enim vult Deus, miseretur, et quem vult, indurat. Non enim tales inviti salvandi sunt, sed volentes, ut integra sit forma justitiae. Sicut enim homo proprii arbitrii voluntate serpenti obediens periit: sic vocante se gratia Dei, propriae mentis conversione homo quisque credendo salvatur. Ergo non vi, sed liberi arbitrii facultate, ut convertantur, suadendi sunt, non potius impellendi. Qui autem jampridem ad Christianitatem coacti sunt venire, (sicut factum est temporibus religiosissimi Principis Sisebuti) quia jam constat eos Sacramentis divinis sociatos Baptismi gratiam suscepisse, et chrismate unctos esse, et corporis et sanguinis Domini extitisse participes, oportet, ut fidem quam etiam vi, vel necessitate susceperunt, tenere cogantur, ne nomen Domini blasphemetur, et fides, quam susceperunt vilis et contemptibilis habeatur».

Encontra-se na Concordia Discordantium canonum, Distinctio $\mathrm{XLV}$, canon V, designado também por Decreto de Graciano, que vem totalmente transcrito no Corpus Juris Canonici, Emendatum et notis illustratum, Gregorii XIII. Pont. Max. Jussu editum, Libro VII. Decretalium, et Jo. Pauli Lancelotti Institutionibus adauctum, Tomus Primus, Augustae Taurinorum, MDCCXLV, ex Typographia Regia, p. 144 .

(3) Sobre os Judeus, cf. Ordenações Afonsinas, Livro II, Fund. Calouste Gulbenkian, 1984, pp. 516-517:

«E nos querendo seguir as carreiras dos Padres Santos nossos antecessores Papas Calisto, Eugenio, Alexandre, Celestino, Inocencio, Gregorio. Nicolaao o Nono, Nicolaao o Quarto, recebemos as petiçõoes, e querellas dos ditos judeos, outrogamos-lhe a defesa, e deffensom de nosso poderio. E porem estabelecemos, e mandamos, que nenhum 
castelhano, entre 1312 e 1317 ou mais provavelmente em 1316, e posteriormente traduzida para português em $1399\left(^{4}\right)$ sob o mesmo título. Pois se, por um lado, aceitava a referida doutrina tradicional da igreja quanto ao baptismo dos judeus, e tinha presente o conteúdo do citado canon, diferente era a sua opinião em relação aos mouros, como ressalta dos três textos que à frente transcrevemos e que foram extraídos dos capítulos 53, 54 e 55 do seu Livro das Confissões $\left({ }^{5}\right)$.

crisptãao nom costranga os ditos judeos per força, ou contra sua vontade, ou tallante a receber o Sacramento do Santo Bautismo».

Para os mouros, idem, Livro II, Título CXVIIII, p. 561:

«El Rey Dom João, etc. em seu tempo fez Ley, per que estabeleceo, que nenhũu Chrisptãao nom costrangua algũu Mouro, que per força, e contra sua vontade aja de receber Sacramento de Bautismo».

O objectivo essencial deste trabalho é focar, apenas, o problema do baptismo das crianças dos mouros e dos judeus, segundo Martín Pérez, e confrontar a opinião deste autor medievalista com as teses, sobre o mesmo tema, de Tomás de Aquino e de J. Duns Escoto, quase seus contemporâneos, insinuando, simultaneamente, a protunda repercussão ao longo dos tempos.

Para as inúmeras obras e artigos, de tantos e tão notáveis autores portugueses e estrangeiros, que se ocuparam de temas relacionados com os mouros, mas sobretudo dos judeus, nunca será demais relevar os valiosos trabalhos de Maria José Pimenta Ferro Tavares, onde esses autores se encontram abundantemente referenciados quase totalmente, para não dizer na totalidade, sobretudo nos seguintes estudos que destacamos: Os judeus em Portugal no século XIV (Lisboa 1979); Os judeus em Portugal no século XV (Lisboa, 1982-1984), 2 vols.; "A revolta dos mesteirais de 1383», in Jornadas Arqueológicas, Associação dos Arqueólogos Portugueses, Vol. I, Lisboa, 1978, pp. 357-383; «Revolta contra os judeus no Portugal medieval», Revista de História das Ideias, n.॰ 6, 1984, pp. 161-173; Judaísmo e Inquisição, Lisboa, 1987 e as «Comunidades Judaicas das Beiras durante a Idade Média», Revista Altitude, Ano II, 2." Série n. ${ }^{\circ}$ 4, Dez. de 1981, Guarda, 1981, pp. 5-15.

(4) Sobre a data do texto castelhano, como da tradução portuguesa e ainda sobre a descrição dos manuscritos encontrados em Espanha e Portugal e dispersos pelas bibliotecas de Leão, Madrid, Montserrat, Toledo, Sevilha e Lisboa, ver o artigo muito completo e altamente bem documentado de António Garcia v Garcia e Jesús M. Múgica, primeiramente publicado na revista Itinerarium 20, 1974, pp. 137-151 e depois em Estudios sobre la canonistica portuguesa Medieval, Madrid, 1976, pp. 201-217 do mesmo autor A. Garcia y Garcia.

Está a ser preparada a publicação duma ediçao tanto da obra em castelhano, como do texto português, por uma equipa de investigadores espanhóis e portugueses, sob a direcção do Prof. António Garcia y Garcia, da Universidade de Salamanca.

(5) Igualmente se encontram no texto castelhano nos mesmos capítulos 53,54 e 55 . 
2. Esta obra em português é constituída por dois grandes códices da Colecção Alcobacense (Cód. CCLI/377 e CCLII/378), actualmente existentes na Biblioteca Nacional de Lisboa, ambos em letra gótica, mas escritos por dois copistas ou tradutores diferentes $\left({ }^{6}\right)$.

Trata-se, duma tradução portuguesa do Libro de las Confessiones, do referido autor, porque ao confrontarmos as duas obras verificámos que embora falte à portuguesa toda a segunda parte da obra de Martín Pérez, o facto é que, tanto a primeira, como a terceira parte, são quase escravas da letra do texto castelhano, com pequenas alterações, que, a nosso ver, não afectam a substância doutrinal $\left({ }^{7}\right)$.

O texto português abre as suas páginas com uma introdução igual à obra castelhana, constituída pela invocação do nome de Deus Padre... um verdadeiro Deus, começo e fim de todalas cousas $\left({ }^{8}\right)$.

E depois também em total submissão literal, segue o texto castelhano, revelando pouco a pouco, o mistério das suas páginas, começando por indicar com fina delicadeza e sempre acompanhada da Sagrada Escritura, que a obra se destina, essencialmente, aos clérigos minguados de ciência,

( $\left.{ }^{8}\right)$ Para a descrição e um estudo mais aprofundado destes Códices Alcobacenses, ver também os trabalhos de investigação de Mário Martins: "O Livro das Confissões de Martim Pérez (Séc. XIV)", Revista Portuguesa de Filosofia, VI, 1950, pp. 156-167 ou sob o mesmo título in Estudos de Literatura Medieval, Braga, 1956, pp. 81-92 e O Penitencial de Martim Pérez em Medievo Português, Separata de Lusitana Sacra, t. II, Lisboa, 1957. Há ainda um outro Códice Alcobacense, o CCLXXIV/ - a/213 com alguns fragmentos do Livro das Confissões, sobre o Sacramento da Penitência, mas que não nos parece de grande relevância.

( ${ }^{7}$ Uma dessas alterações diz respeito à divisão da obra em quatro partes pelo tradutor português, dividindo tanto a primeira como a terceira cada uma em duas, quando o texto castelhano completo se apresenta dividido em três partes. Um outro aspecto diferente é notar-se, a cada passo, a introdução no próprio texto português de citações de fontes que nalguns códices castelhanos aparecem à margem.

Seja-nos permitido aproveitar esta oportunidade para sinceramente agradecermos ao Prof. António Garcia y Garcia a gentileza em nos ter cedido todo o texto castelhano a fim de podermos fazer este confronto com os Códices Alcobacenses.

( $\left.{ }^{8}\right)$ O texto castelhano que vai ser editado oferece ao leitor, antes da introdução, o elenco dos 180 capítulos, enquanto a tradução portuguesa nos Cótlices Alcobacenses abre de imediato com a introdução e só depois desta apresenta, apenas em parte, o enunciado dos capítulos. 


\section{Liberdade de Religião}

isto é, aos que têm fome e que andam à busca e à espera das migalhas que caem das mesas dos senhores, que são ricos de letras. Acentua, seguidamente, que não se dirige aos avarentos e soberbos da cultura, que passam indiferentes aos que lhe estendem a mão a pedir esmola, pois contra esses levanta-se a condenação do Evangelho: Vae vobis! Ai de vós, sabedores da lei, que tendes a chama da sabedoria, porque nem entrais, nem deixais entrar os que querem. Destina-se, antes, aos que não sabem e que andam ao restolho da Escola, para acolher as espigas das Escrituras.

Ora, é neste contexto, que tem razão de ser o capítulo destinado aos mouros e aos judeus, escrito sobretudo para os clérigos directores de consciência, para que mais facilmente orientem os crentes, sempre que surjam situações semelhantes, como os dois textos sugerem e que a seguir transcrevemos:

«53. Se pode algũu cristão furtar os filhos pequeninos dos mouros para os bautizar.

Outra questom fazem aqui os doutores e porque acontece de feito algũas vegadas, convem que se escreva: Se os cristãos furtarem os mouros, pequeninos, filhos dos mouros para os bautizar, sem pecado, ou se pecam aqueles que tal furto fazem. A esto dizem os doutores: que se a entençom do cristão, que tal furto faz, é dereita e que com piedade das almas de as dar a Deus e com amor da fe se moveo a fazer tal furto, nom peca, ante gaanha mercee. $\mathrm{Ca}$ nom faz a nehũu injuria nem torto a los padres nom. Ca os desvia do pecado, que queriam envolver e cegar os seos filhos em nas ceguidades suas. $\mathrm{E}$ esto seeira razom de maior damnaçom para os padres aos filhos, ca os livra do poder do diabo, e da carreira do inferno, e trague-os aa carreira da vida. Hec dicta sunt doctorum $\left({ }^{9}\right)$.

54. Se podem os cristãos furtarem os filhos pequeninos dos judeos para os bautizar

Dos filhos dos judeos que som pequeninos e sem idade, nom é assi. Sic. Glo. sup. ilud. c. Judeorum filios. XXVIII. q. I ${ }^{\left({ }^{10}\right)}$. Ca os judeos segundo diz o dereito e os

(9) Martim Pérez, Livro das Confissões, cap. 53, Cód. CCLI/377.

(10) Esta referência ao Decreto de Graciano, que por sua vez evoca o IV Concílio de Toledo, é a seguinte: «C. XI. A parentum infidelium separentur consortio fideles filii ne eorum involvantur erroribus. 
doutores. som servos dos principes e dos senhores cristãos em cujas terras vivem. Et. eodem. c. Et si judeos XXIII. q. VIII. c. Dispar (11) e Genesi. IX. c. Maledictus Chanaan servus servorum erit (12). E assi os filhos pequeninos mais som em poder dos senhores. que dos padres judeos. E por esto nom pode nehũu tomar estes maes pequeninos para os tornar cristãos sem mandado dos padres deles. nem sem o principe cristão. que ha o senhorio da terra du vivem. E esto é verdade como diz o

Judaeorum filios vel filias, ne parentum ultra involvantur erroribus, ab eorum consortio separari decernimus deputatos aut monasteriis, aut Christianis viris, aut mulieribus Deum timentibus ut sub eorum conversatione cultum fidei discant, atque in melius instituti tam in moribus quam in fide proficiant» (Corpus iuris canonici, ob. cit., 948).

Deste modo o autor (tradutor ou comentador) remetendo assim para o referido texto pretendia recordar igualmente outro ponto da legislação que, em certo modo, completava a teoria presente, como que a querer dizer: atenção, se por um lado não se devem furtar os filhos pequeninos dos judeus para os baptizar, é lícito, no entanto, separar do convívio dos pais infiéis os filhos convertidos à fé, a fim de que se não envolvam nos erros dos seus pais e mais facilmente possam crescer e progredir na fé cristã.

Contudo, o mesmo IV Concílio de Toledo, de que também Graciano se faz eco, decreta, a propósito dos judeus ${ }_{2}$ como já se referiu atrás, que ninguém deve ser forçado a crer: De judaeis autem praecipit sancta Synodus, nemini deinceps ad credendum vim inferri... (Corpus iuris Canonici, ob. cit., Dist. XLV, c. V, 144).

(11) Trata-se da desigualdade de tratamento pelos cristãos relativamente aos mouros e aos judeus. Enquanto estes não devem ser perseguidos porque são úteis em toda a parte, os sarracenos devem-se combater, e justamente, porque ocuparam violentamente a terra, expulsando os cristãos das cidades e dos seus lugares: «C. XI. Judaeos non debemus persequi, sed sarracenos. Item Alexander Papa II, omnibus Episcopis Hispanie. (1066).

Dispar nimirum est judaeorum et sarracenorum causa. In illos enim, qui Christianos persequuntur, et ex urbibus, et propriis sedibus pellunt, juste pugnatur: hi vero ubique servire parati sunt" (Corpus iuris Canonici, ob. cit., causa XXIII, q. VIII. c. XI, 831-834).

(12) Clara alusão à maldição referida no Génesis IX, 25-26, lançada por Noé sobre o seu filho Cam. A figura de Noé representa o tipo do homem justo que se liberta do castigo e beneficia da salvação. No meio do dilúvio da iniquidade, que destrói o mundo, emerge como alvor duma humanidade nova, prefiguração de Cristo. Mas apesar desta benevolência divina o homem pode falhar, como Noé, que se deixa embriagar. Cam, homem de maus costumes, ridiculariza o pai que, sentindo-se humilhado, faz recair sobre o filho a sua maldição: "Maldito seja Canaan, disse ele: que ele seja o último dos escravos de Israel. E acrescentou: bendito seja o Senhor Deus, de Sem, e Canaam seja seu escravo". Assim recaiu, de igual modo, sobre os judeus, uma maldição semelhante. 
dereito. e os doutores. Convem ao confessor que diga aos reis e aos principes e aos pralados, que tal senhorio ham sobre os judeos quando si confessarem que tomem conselho sobre taes cousas. ou homees prudentes e sabedores e tementes Deus. e façam aquilo que seja mais serviço de Deus. ca determinhado é por dicto dos sanctos em no dereito. que os judeos e os maos devem seer constrangidos com tribulaçõoes e com quebrantos por tal que venham a boa carreira. Ca por temor da pena desusaram e desacostumaram o mal. e por o bõo uso e costume pagar-se-am do bem e namorar-se-am dele. $\mathrm{E}$ assi o uso do bem lhes fara saboroso. $\mathrm{O}$ que ao começo lhes era amargoso. XXIII. q. VI. c. Jam vero (13) e seq. usq. in finem.

55. Das molheres cristãas que criam filhos de judeos se os podem bautizar a furto. Preguntas dos damnos e das perdas e dos enganos feitos a mouros e a judeos e a cristãos e de como se deve fazer emenda deles.

Per as razõoes de suso dictas parece. segundo dizem os doutores que as molheres cristãas que contra defendimento da egreja. criam filhos de judeos. que nom devem a turto bautizar los nem outro nehũu que seja. por o que é dicto. E outrossi por o grande perigo que poderia acontecer. Que se os bautizassem assi a furto. e nom os tirassem do poder do padre. e dos outros emmigos da fe. ficariam em maiores erros. Que os reis quisessem tirar do poder do padre nom poderiam provar o bautismo. que se fez a furto. Mormente como dicto é. que nom é nehũu desto poderoso. se nom o rei ou o senhor deles. E esto mesmo cuidamos que pode seer dos filhos dos mouros que vivem antre os cristãos. $\mathrm{E}$ assi fica o encarrego desto todo aos reis. e sobre os principes e senhores deles. Dicta sunt doctorum... Ca a lei de Jesus Cristo manda bem fazer aos judeos e aos pagãos e a cristãos. e nom manda a nehũu fazer mal nem damno em nem ũa maneira. Onde. Diligite inimicos nostros benefacite his. etc. Mat. V (14). Estote misericordes sic, etc. Luc. VI (15). Non tantum bonis et modestis. sed etiam discolis. 1 Pet. II ${ }^{\left({ }^{16}\right)}$.

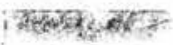

(13) Refere-se ao texto: "Onere pensionis Rusticus ad Dominum converti cogatur.

Item Gregorius Januario Episcopo Caralitano, lib. 3, epist. 26.

Jam vero, si Rusticus tantae perfidiae, et obstinationis fuerit inventus, ut ad Deum minime venire consentiat, tanto pensionis onere gravandus est, ut ipsa exactionis suae poena compellatur ad rectitudinem festinare (Dec. II Pars, Causa XXIII, q. VI, c. IV).

(14) Mat. V, 44 e Luc. VI, 27.

(15) Luc. VI, 36.

(16) Pet. II, 18. 
3. O autor destes textos, como já se referiu, é Martín Pérez que se revela não só como um mestre de Teologia Moral, mas sobretudo como conhecedor do Direito e das principais correntes do pensamento da sua época.

Mas a questão sobre a sua identidade está longe de ficar completamente resolvida. Não admira, por isso, que investigadores espanhóis e portugueses ainda se interroguem quem era Martín Pérez.

Assim, entre nós, Joseph M. Piel, ao editar o Leal Conselheiro, do rei D. Duarte, onde este monarca manifesta o seu apreço pelo Livro das Confissões, não deixou de levantar, numa simples nota de fundo de página e sem mais delongas, a seguinte pergunta: «Tratar-se-á de Martim Pires que vivia como conselheiro na corte de D. Dinis»? A obra será idêntica ao Livro das Confissões? ( ${ }^{17}$ )

(17) Esta interrogação, sem qualquer outro desenvolvimento, obrigou-nos a retomar a questão sobre a identificação do autor das Confissões e a procurar uma resposta para a pergunta de J. M. Piel parando por momentos, diante dessa personalidade que foi Martim Pires ou Peres, o grande colaborador, conselheiro e procurador do rei D. Dinis que, à semelhança de alguns dos monarcas seus antepassados, mas sobretudo do seu avô, o rei sábio $\mathrm{D}$. Afonso $\mathrm{X}$, de Castela, soube rodear-se não só de bons juristas, mas de outros peritos nos mais diversos sectores da governação, sem os quais era impossível levar a cabo tão vasta e grandiosa obra que nos legou e que historicamente assinalou D. Dinis como um dos maiores reis de Portugal.

Martim Pires nasceu em Évora, de Pedro Pires de Oliveira e de D. Elvira Annes Pestana. Era irmão de D. Ozenda, mãe dos bispos de Evvora, D. João e D. Martinho de Brito e em 1277 aparece como clérigo do rei e cónego de Braga. Em 1295, foi confirmado arcebispo de Braga pela bula Onerosa pastoralis de Bonifácio VIII, e é vulgarmente designado por D. Martinho Pires d'Oliveira. Cf. Francisco da Fonseca, Evora Gloriosa - Epílogo, Roma, MDCCXXVIII, p. 327; José Augusto Ferreira, Fastos Episcopaes II, Braga, 1930. pp. 94-113.

Em 4 de Abril de 1296 encontrava-se em Braga, à frente dos destinos da sua Diocese, havendo até notícias da celebracão naquele mesmo ano dum Sínodo (ou duma Constituição episcopal) relativa aos problemas do clero (Cf. António Garcia y Garcia, Synodicon Hispanium II - Portugal, Madrid, MCMLXXXI, p. 31).

Esta mesma solicitude pelo clero revela-se nas conhecidas Constituições elaboradas num novo Sínodo de 7/9/1301 (Idem, pp. 31-38).

O seu espírito conciliador, levou-o a inúmeras permutas, composições e até doações, quer com os outros bispos, quer com o rei ou outras pessoas e instituições, o que prova, apoditicamente, que se tratava dum prelado liberal e zeloso. (J. A. Ferreira, ob. cit., pp. 106-113 , onde remete para uma vastíssima documentação). 
De facto, o nome de Martim Pires anda ligado a alguns dos mais notáveis documentos históricos, entre os quais destacamos, pela sua relevância, a Concordata de 1289, celebrada em Roma, na presença do Papa Nicolau IV (1?88-1292), onde esteve como procurador do rei e da qual foi o grande obreiro, com João Martins, cónego da Sé de Coimbra $\left({ }^{18}\right)$ e ainda as Concordatas de $1292\left({ }^{19}\right)$ e $1309\left({ }^{20}\right)$, todas elas realizadas para sanar os conflitos entre os bispos e o monarca. Mas o seu nome figura, igualmente, no Tratado de Alcanizes (Espanha, 12/9/1297) e no segundo Testamento do rei (de 8/4/1299) em que é nomeado testamenteiro de D.

De 16 de Outubro de 1311 a 7 de Maio de 1312 participa no Concílio de Viena, no qual Clemente V, com o acordo dos bispos, extingue a Ordem dos Templários e deu um novo impulso à festa do Corpo de Deus por toda a cristandade do Ocidente Medieval.

Depois do Concílio permanece em Avinhão, talvez como procurador de D. Dinis para tratar da questão da aplicação dos bens dos Templários, onde adoece e veio a morrer em 25 de Março de 1313 (Idem, pp. 109-113).

Justifica-se que Joseph M. Piel tenha levantado a pergunta se seria Martim Pires, conselheiro de D. Dinis, o autor do Livro das Confissões, como que a sugerir uma posterior investigação sobre a questão.

E que o espírito do Livro das Confissões encontra-se perfeitamente não só dentro do contexto cultural, social e político-religioso do período, mas também se harmoniza perfeitamente com a personalidade, preocupações e acção pastorais de Martim Pires, sobretudo depois da sua elevação ao prestigioso arcebispado de Braga.

(18) Previamente a esta Concordata de 1289 tinha havido um acordo já em 1282 para o qual os bispos e o rei se reuniram na Guarda em que, provavelmente, Martim Pires participou.

Sobre esta reunião e o respectivo acordo e a intervenção do papa Martinho IV, cf. Fortunato de Almeida, História da Igreja em Portugal. Vol. I, Porto, 1967, p. 200. Para as bulas papais cf. Visconde de Santarém, Quadro Elementar IX, Lisboa, 1864, pp. 227-229 e 239. Cf. também Monarquia Lusitana, Parte V, L. XVI, cap. XXXVI. Vide carta de procuração de D. Dinis de 5 de Junho de 1288 in Quadro Elementar cit. 256 (Nicolau IV aprovou a Concordata pela bula Cum Olim, 7/3/1289 como se pode verificar in Quadro Elementar cit., pp. 241-255); Cf. Fortunato de Almeida, ob. cit., pp. 201-202; idem, IV, pp. 61-69 para a transcrição da Concordata ou em Ordenações Afonsinas II, Coimbra, 1972, pp. 3-32. Sobre as razões da demora na solução da questão, cf. José Mattoso, Identificação de um País, vol. II, Lisboa, 1985 , pp. $160-161$.

(19) Cf. Fortunato de Almeida, ob. cit., p. 202 e Vol. IV, pp. 70-73; Ordenações Afonsinas cit.. pp. 33-44; Quadro Elementar cit., pp. 278-286.

(20) Cf. Ordenações Afonsinas cit., pp. 47-61; Quadro Elementar, pp. 298-305; Fortunato de Almeida, ob. cit., IV, pp. 76-80. 
Dinis, conselheiro da Rainha e tutor do seu filho, o infante D. Afonso $\left({ }^{21}\right)$.

Além disso, seguindo o itinerário do grande conselheiro de D. Dinis. desde 1277, aparece-nos sempre como uma insigne figura de diplomata, principalmente nas grandes discórdias entre a coroa e o clero e de um homem culto e conciliador, e aparentemente de espírito liberal, deixando assim na história da Igreja a memória de conselheiro inteligente, zeloso e eficaz.

Não repugnava por isso, que este conselheiro e confidente de D. Dinis fosse o autor do Livro das Confissões, se não surgissem outras dificuldades que de momento, parecem inultrapassáveis.

Assim, torna-se difícil, para não dizer impossível, conciliar a data da morte deste conselheiro de D. Dinis, Martim Pires, ocorrida em 25/3/1313 com a data do aparecimento do Libro de las Confessiones que tudo leva a crer que tenha sido entre 1312 e 1317 ou mais concretamente em $1316\left({ }^{22}\right)$.

Também nada consta acerca dos estudos no estrangeiro ou da existência de escritos deste Martim Pires. Os únicos documentos que nos restam e a que o seu nome anda vinculado, duma forma impessoal, resumem-se à notícia do Sínodo de 1296, mais provavelmente constituição episcopal, relativa à proibição de conceder novos prestimónios nas igrejas paroquiais e às constituições do Sínodo de 1301 que, por sinal, são em latim.

Também não achamos lógico que um português, no caso presente, Martim Pires, tivesse escrito o Livro das Confissões em língua castelhana e não em português, como seria natural, tanto mais que no reinado de D. Dinis o vernáculo era já larga e oficialmente usado.

Se o autor fosse português e tivesse escrito em castelhano seria natural que aparecessem também manuscritos do Livro das Confissões em língua castelhana nos arquivos portugueses, o que não acontece, e não apenas a tradução portuguesa.

A tradução portuguesa do Livro das Confissões enquadra-se perfeita e logicamente dentro da tradução das melho-

(21) Cf. Monarquia Lusitana, Parte V, L. XVII, cap. XXXIX e ainda na mesma obra Escritura 34 e 35.

(22) António Garcia y Garcia aponta a data de 1316, tendo em consideração não só as citações na referida obra sobre o "direito novo" ou do Livro VI de Bonifácio VIII (1294-1303) e que foi promulgado em 1298 e ainda as referências a algumas constituições de Clemente V 
res obras de natureza semelhante que também foram traduzidas para português e que são a melhor prova de que não existiam barreiras culturais entre Portugal e Espanha.

De facto em Portugal existiram, desde o séc. XIII, como fontes subsidiárias do direito, certas obras teóricas de origem castelhana, como as Flores de Derecho ou Flores de las leys e a Summa de los noue tiempos de los pleitos de Mestre Jácome das Leis e ainda o Fuero Real e as Siete Partidas da iniciativa de Afonso $\mathrm{X}$, o Sábio, que tiveram em Portugal grande divulgação e aceitação desde o séc. XIII ao séc. XV, não só através de numerosas cópias e traduções, mas também da sua ampla aplicação em detrimento, até, dos textos do Direito Romano.

As obras de Jácome das Leis e o Fuero Real chegaram até nós através duma cópia do séc. XIII, contida num códice designado por Foros da Guarda existente no Arquivo Nacional da Torre do Tombo e que Paulo Merêa datou entre 1273 e 1282 .

Porém, a utilização e divulgação das Siete Partidas foi ainda muito mais vasta, pois embora se não conheça nenhuma tradução completa dos séculos XIII a XV, chegaram até nós numerosos fragmentos desta obra que ainda hoje existem em algumas das nossas bibliotecas e arquivos, tanto no original castelhano como em texto português, o que atesta bem o uso e a influência nos juristas da corte portuguesa $\left({ }^{23}\right)$.

Não é de estranhar, por isso, que o autor do Livro das Confissões fosse do país vizinho e que a sua obra, como tantas outras, se difundisse rapidamente entre nós e merecesse ser quase imediatamente traduzida, em 1399, dentro desta normal tradição. Tanto mais que é dotada de características muito semelhantes às Siete Partidas e a outras obras castelhanas.

(1305-1314) que então formavam parte da colecção das Clementinas promulgadas mais tarde, pelo papa João XXII em 1317, mas sobretudo o testemunho do próprio autor, pelo menos quanto à segunda parte da sua obra, que diz textualmente: «nuevecientos años son complidos en la era de la encarnación de Jesu Cristo de mill et tresientos et dies et seys, o cerca de complidos en la qual era fue fecho este libro" (cf. A. Garcia y Garcia, Estudios sobre la canonistica Portuguesa Medieval, Madrid, 1976, pp. 212-213.

(23) Sobre toda esta matéria é justo salientar-se o trabalho que nos legou o Prof. Doutor Guilherme Braga da Cruz, da Faculdade de Direito, da Universidade de Coimbra, intitulado «O direito subsidiário na história do direito português», Revista Portuguesa de História, 
4. O facto do autor escolher a língua vulgar, para assim melhor se aproximar da vida quotidiana e dos problemas humanos, e não o latim que era inacessível aos leigos e até a grande parte do clero, representa, para a época, um assinalável progresso pastoral e uma notável preocupação evangélica que, quase parece - dada a difusão da obra na Península Ibérica - , corresponder, de facto, a uma premente necessidade do clero, como, aliás, o próprio texto refere.

O certo é que a obra andava de mão em mão, não apenas dos monges dos mosteiros, mas também nas dos leigos, possivelmente mais preocupados em seguir os ditames da sua consciência de cristãos e talvez mesmo mais sensíveis aos ensinamentos do "pobre Livro das Confissões».

Não admira, por isso, que alguns dos manuscritos se achassem disseminados por bibliotecas particulares como a do Conde de Haro fundada em 1445: a de D. Fernando Colón, irmão de Cristóvão Colombo, o descobridor da América ${ }^{(24)}$ e nas bibliotecas do rei de Portugal D. Duarte (1391-1438) e de seu irmão D. Fernando, o Infante Santo (1402-1443).

D. Duarte, não lhe poupou elogios e cita-a directamente, o que demonstra que esta obra lhe era bastante familiar, como se verifica no seu Leal Conselheiro: «E porem grandemente e per muytas partes os senhores erramos e caymos em el, por que a tantas cousas somos obrigados de bem fazer, as quaaes leixamos ou bem nom comprymos por seguyr voontade, vencendonos per fraqueza e assy obrando outros feitos, em aue nosso tempo ou bees despendemos no que poderiamos bem scusar, segundo se podera veer em huũ livro que chamam de Martym Pires, em que toca os pecados que perteecem aos senhores de mavor e mais somenos estados" $\left({ }^{25}\right)$. E no fim do capítulo LXVII volta novamente a referir-se, recomendando a sua leitura: E dos pecados que perteecem a

Tomo XIV, vol. III, Coimbra, 1974, pp. 176-316. Cf. José Mattoso, ob. cit., pp. 95-96.

Quanto à identidade de Martín Pérez ver ainda as várias hipóteses em A. Garcia y Garcia, Estudios sobre la canonistica portuguesa medieval, Madrid, 1976, pp. 209-211. Cf. Mário Martins, art. cit., pp. 61-62; A. Domingues Sousa Costa, Itinerarium II, 1956, pp. 261-262 (recensão a Mário Martins, Estudos de Literatura Medieval, Braga, 1956) onde levanta o problema de autoria; F. Elias Tejada Spinola, Las Doctrinas Politicas en Portugal (Edad Media), Madrid, 1943, p. 152.

(24) Cf. António Garcia y Garcia. Estudios sobre la canonistica portuguesa medieval, Madrid, 1976, pp. 205 e 206.

${ }^{(25)}$ Dom Eduarte, Leal Conselheiro, ed. crítica de Joseph M. Piel, Lisboa, 1942 , p. 102 . Cf. Mário Martins, ob. cit., p. 82 e art. cit., pp. $63-64$. 
cadahuũ estado, en huũ livro que fez huũ que sse chama Martym Pires, he feita boa declaraçom segundo vos já demostrei. E quem delles quyser aver comprida enformaçom, veja o dicto lyvro, por que lhe dara ello grande ajuda" $\left({ }^{26}\right)$.

Que o rei português possuía, de facto, Dous livros de Martim Pirez, é inegável, pois a obra consta do catálogo de livros que tinha El Rey Dom Duarte $\left({ }^{27}\right)$.

Também o Infante D. Fernando mostra que conhecia a mesma obra, tanto assim que em 10 de Junho de 1431 escrevia uma carta ao abade de Alcobaça a pedir-lhe emprestado o treslado do Livro de Martim Pires: "Prior e convento do Mosteiro de Alcobaça. O Infante D. Fernando vos envio muito saudar. Faço-vos saber que a mim prazeria aver o treslado do livro de Martim Pires que nesse mosteiro tendes. Por ende vos rogo e encomendo que vos praza de mo enviardes pelo Portador 2 e tanto que o eu ouver tresladado volo mandarei tornar, e fazerme eis um esto prazer e serviço que vos agradecerei. Escrito em Torres Vedras 10 de Junho. João Alves a fez, 1431 annos» $\left({ }^{28}\right)$.

A influência do Livro das Confissões ou de uma obra análoga e a sua repercussão doutrinária e pastoral, ressalta

(26) Idem, p. 272.

(27) Idem, p. 416 .

(28) Cf. Fr. Fortunato de S. Boaventura, Historia chronologica.... de Alcobaça, Lisboa, 1827, p. 36.

Parece não haver grandes razões para duvidar de que se trata do Livro das Confissões, de Martim Pérez, referenciado nas citações tanto de D. Duarte, como de seu irmão, D. Fernando, o Infante Santo, e pertencente ao núcleo Alcobacense da B.N.L.

Júlio da Costa Pimpão, História da Literatura Portuguesa, 1 (Séculos XII a XV), Coimbra, 1974, p. 43, afirma, sem mais delongas, que se trata provavelmente do Livro das Confissões que existiu no Mosteiro de Alcobaça. Mário Martins, ob. cit., p. 82, transcreve a carta e sem qualquer objecção aceita que se trata muito provavelmente do Livro das Confissões e repete a mesma ideia em «Penitencial de Martim Pérez em medievo português», Lusitana Sacra II, pp. 57-110.

Adelino de Almeida Calado, Frei João Alvarez (Estudo textual $e$ literario-cultural) ${ }_{2}$ Coimbra, 1964, pp. 198-200, adianta, referindo-se às duas opiniões anteriores, que não há razão para dúvidas, uma vez que existe a obra em dois volumes, nos códices CCLI/377 e CCLII 1378 e que não há notícia de outra obra do mesmo autor que levante hesitaçốes. E acrescenta que a cópia que o Infante desejava não chegou a realizar-se porquanto nenhuma alínea do testamento se lhe refere, mas que nem por isso a referida carta perdia o seu valor como testemunho de interesse cultural. 
também no Diálogo de Robim e do Teólogo, de autor anónimo, mas talvez português $\left({ }^{29}\right)$.

Trata-se duma pequena obra, semelhante, na nossa opinião, a um catecismo prático, onde afloram princípios básicos e essenciais sobre os principais artigos da fé cristã, os sacramentos, as obras de misericórdia, os mandamentos, as virtudes, os pecados mortais, a herança, os problemas dos religiosos, o escândalo, etc., mas num texto fácil, menos extenso, sempre em forma de diálogo, e por isso mais acessível, quase a oferecer a solução ou a resposta para os problemas mais correntes do dia a dia.

Ora toda esta matéria é tratada duma maneira mais vasta e mais desenvolvida, como é óbvio, no Livro das Confissões. Por isso foi-nos grato registar não só a profunda influência deste no Diálogo de Robim, que mais parece um derivado da obra de Martín Pérez, mas também assinalar a transcrição quase literal, na maior parte dos casos, de passagens inteiras do livro de Martín Pérez pelo referido Diálogo.

Não se trata duma síntese do Livro das Confissões, mas sim duma selecção de textos tirados provavelmente deste Livro ou elaborados com forte inspiração na mesma obra, bem ordenados, com lógica. e escolhidos como resposta a questões previamente formuladas com base nos mesmos. Torna-se, assim, num guia de fácil manuseamento, sem qualquer preocupação de seguir a ordem dos capítulos do Livro das Confissões ou de transcrever tudo seguidamente. As vezes, como resposta às perguntas que Robim vai fazendo ao

${ }^{(29)}$ A obra encontra-se no Cod. Alc. CCXCI/200, fls. 195r-219v, existente na Biblioteca Nacional de Lisbaa, e já editado por Henri Hare Carter, Paleographical edition and study of the language of a portion of codex Alcobacensis 200 (Filadélfia 1938). No texto que abaixo citamos, respeitamos, totalmente, os critérios que $\mathrm{H}$. Carter seguiu na transcrição, embora discordemos em algumas partes.

Mas foi Mário Martins que assim o intitulou por a obra principiar do seguinte modo:

«Era hũu pphilosafo Jentil. que oue nome Robim deseiaua mujto deseer christaao Essoube parte dehuũ grande meestre e tooligia e foise perael. aseer seu discipolo que lhe e sinase afe de christo El por perguntar Eo meestre por rresponder Effazianse huũ ao outro Estas prreguntas. que se segem pprimeiramte Meestre Dime quantas som as cousas que cõprem aohomem pera seer uerdadeiro christaao.» Henri H. Carter, ob. cit., p. 37. Cf. Mário Martins, ob. cit., pp. 447-453. 
Mestre, o autor escolhe do mesmo capítulo as passagens que mais lhe interessam, saltando o texto constantemente e adaptando-as em ordem a corresponder e a tranquilizar mais apoditicamente o discípulo.

Deste modo, o autor do Diálogo de Robim deveria conhecer perfeitamente o Livro das Confissões ou obra similar onde foi buscar a resposta que the parecia mais adequada aos problemas da pastoral do seu tempo $\left({ }^{30}\right)$.

Não admira esta influência e difusão do Livro das Confissões, de Martín Pérez. Trata-se de um autêntico manual de confessores que reflecte, com certa profundidade, a ciência teológico-jurídica da Idade Média acerca dos problemas das mais diferentes classes sociais da época.

Religiosos, leigos, bispos, grandes senhores, reis, serviçais, o trabalho, a ociosidade, a usura, empréstimos, escravatura, salários, mandamentos, furto, sacramentos, sepultura eclesiástica, esmolas, feiras, mercados superstição, bruxedo, mouros, judeus, obras de misericórdia, virtudes, etc., etc., tudo tem de passar e é analisado pelo espelho da Teologia Moral. E nisto consiste, quanto a nós, a grande riqueza do pobre Livro das Confissões, como lhe chama o seu próprio autor.

Ora é neste contexto que se insere a presente doutrina teológico-jurídica sobre o baptismo dos filhinhos dos mouros e dos judeus.

5. Perante os textos em confronto, conclui-se, que segundo Martín Pérez, furtar os filhos pequeninos dos mouros, para os baptizar, mesmo contra a vontade dos pais, nunca será pecado, podendo até ser uma obra meritória, desde que se proceda com recta intenção, com piedade das almas de as dar a Deus e com amor de fé, como dizem os doutores.

(30) A investigadora Helena Pardo, da equipa dirigida por A. Gancia y Garcia, encontrou um derivado da obra de Martim Pérez, de natureza semelhante ao Diálogo de Robim e do Teólogo, o que prova, mais uma vez, que o Libro de las confessiones era bem conhecido e seguido.

Dizemos ou obra similar porque há muitas outras semelhantes ao Libro de las confessiones. Veja-se sobre esta temática Pierre Michaud-Quantin, Sommes de casuistique et manuels de confession au moyen âge (XII-XVI siècles), Montreal, 1962, onde se destacam as obras de Alain de Lille, Robert de Flamborough, Thomas de Chobham, Paulo de Hungria, João de Deus, Raimundo de Penhaforte, João de Fribourg, Astesanus d'Asti, Bartolomeu de Pisa, etc., etc. 
Primeiro, porque não lesam os direitos dos pais nem se comete contra eles qualquer ofensa. Seguidamente porque os desvia do pecado em que queriam envolver e cegar os seus filhos nas suas cegueiras, o que redundaria em maior condenação para os pais aos filhos e ainda porque os livra do poder do diabo e do caminho do inferno, e os conduz à carreira da vida.

Mas com os filhos dos judeus que são pequeninos, isto é, que ainda não atingiram o uso da razão, os cristãos não os podem furtar para os baptizar $\left({ }^{31}\right)$. Podem, sim (acrescenta a glosa), separar do convívio dos pais infiéis, os filhos já convertidos à fé, a fim de que se não envolvam nos erros dos seus pais e mais facilmente possam crescer e progredir na fé cristã $\left({ }^{32}\right)$. Mas quanto aos judeus sem idade, não é lícito, pois os judeus segundo o Direito e os doutores são servos dos príncipes e dos senhores cristãos em cujas terras vivem e sobre quem têm jurisdição. Além disso, não devem ser perseguidos porque os judeus são úteis em toda a parte, enquanto os sarracenos se devem combater, e justamente, porque ocuparam violentamente a terra expulsando os cristãos das cidades e dos seus lugares ${ }^{(3)}$ ).

Assim, ninguém pode tomar os mais pequeninos para os tornar cristãos sem mandato dos seus pais e do príncipe do senhorio da terra onde vivem.

$\mathrm{E}$ as mulheres cristãs, que contra as prescrições da Igreja, criam os filhos dos judeus, também não os podem baptizar a furto, em virtude do grande perigo em que poderiam cair. Porque se assim procedessem e não os tirassem do poder dos pais e dos outros inimigos da fé, ficariam em maiores erros. $\mathrm{E}$ até se os reis os quisessem tirar do poder dos pais não poderiam provar o baptismo feito às ocultas.

(31) Cf. nota 2. Nunca será demasiado frisar que o Concílio de Toledo, no canon citado se preocupou, primeiramente, em estabelecer um princípio fundamental, que permaneceu inalterável pelos séculos fora: ninguém pode ser forçado a crer.

Contudo, a Igreja, como também o mesmo canon insinua, tomava uma atitude diferente em relação aos hereges e apóstatas, isto é, aos que abandonavam a fé. Fundamentando-se no princípio da legitimidade do poder coercitivo sobre todos os cristãos que, pelo sacramento do baptismo, se tornaram seus membros e súbditos, achava-se no direito de poder obrigar todos os baptizados, mesmo até com castigos corporais, a cumprirem as suas obrigações, pois se aceitar a fé e fazer uma promessa era um acto livre, conservar e cumprir a fe recebida era uma necessidade.

(32) Cf. nota 10 .

(33) Cf. nota 11 
É um assunto que diz respeito totalmente aos reis, aos príncipes e aos senhores deles. E o que se diz em relação aos judeus, é igualmente válido para os mouros.

$\mathrm{O}$ autor para assim falar, tinha certamente presente a situação concreta e específica dos mouros e dos judeus nos reinos cristãos da Península Ibérica. E como claramente prova, conhecia igualmente bem a legislação cristã vigente, sobretudo o Decreto de Graciano, e ainda as sentenças dos Doutores. Daí invocar constantemente a sua autoridade: Haec dicta sunt doctorum.

Teria então presente, ao escrever estes textos, também as opiniões de Tomás de Aquino e de Escoto?

Os textos em análise espelham, quanto a nós, além duma certa doutrina comum, as duas grandes correntes de pensamento então muito em voga, e que agitavam fortemente os homens do poder da Idade Média.

De facto, examinado o tipo de argumentação que o autor nos apresenta, saltam-nos à memória as teorias de Tomás de Aquino e de Escoto precisamente sobre tão candentes questốes, e que vale a pena recordar para melhor se compreender a profundidade dos textos que Martín Pérez escreveu.

Porque a questão ${ }_{z}$ se os filhos dos judeus e dos outros infiéis deviam ou não ser baptizados contra a vontade dos seus pais, era também vivamente discutida no tempo de Tomás de Aquino (1224/5-1274) a quem se deve, por este facto, a mais magnífica defesa dos valores da liberdade religiosa e da ordem jurídica natural perante a ordem sobrenatural da graça.

Teoria, aliás, precisamente contrária à de João Duns Escoto (1265/6-1308), o príncipe da escola franciscana e uma das figuras mais representativas do período áureo da Escolástica e de quem, na nossa opinião, Martín Pérez, teoricamente, mais se aproxima nos referidos textos.

$\mathrm{Na}$ verdade, J. Duns Escoto e mais tarde Gabriel Biel (1425-1495) e John Maior ou Mair $(\dagger 1550$, sem esquecer os defensores da teocracia, como Henrique de Susa, o Hostiense (1200-1271) e Egídio Romano (1243/7-1316) e muitos outros, defendiam a evangelização pela força e consequentemente o baptismo das crianças dos judeus mesmo contra a vontade dos pais, podendo até os príncipes obrigar os seus súbditos a receber a fé. Foi esta mesma teoria que moveu o irrequieto teólogo Ginés de Sepúlveda (1490-1573) a bater-se pela aplicação em Espanha destas mesmas teses para justificar não só as conquistas da América e o direito de compulsão dos 
índios à fé, mas também a espoliação das suas terras e do direito de propriedade em virtude da sua infidelidade e do pecado, como aliás defendiam, também, Gregório de Rimini $(† 1358)$, J. Huss (1370-1415), J. Wiclef (1333-1384) e Ricardo de Fitzralph ou Armacano ( $† 1360)$.

Mas a estas teorias juntavam-se as teses teocráticas e até imperialistas de Egídio Romano ( $\dagger 1316)$, Tiago de Viterbo $(\dagger 1307)$, João de Nápoles, ( $\dagger 1336)$, Alvaro Pais $(\dagger 1349)$, João de Segóvia (†1456) e de tantos outros que não só proclamavam o poder universal do papa sobre todas as nações infiéis, mas também o direito de privar os seus príncipes da própria autoridade $\left({ }^{34}\right)$.

João Duns Escoto ao interrogar-se sobre a questão, se os filhos dos judeus e dos infiéis se devem baptizar contra a vontade dos próprios pais, tem particularmente presente não só a argumentação de Tomás de Aquino, que procura rebater, mas também a opinião de outros Doutores medievais $\left({ }^{35}\right)$.

De toda a sua exposição deduz-se que as crianças recebem os efeitos do baptismo, independentemente da fé dos seus pais e por isso este sacramento pode ser administrado justa e validamente aos filhos pequenos, tanto dos infiéis como dos judeus, contanto que seja recebido dentro de determinados parâmetros.

Daí defender, como tese fundamental, que é permitido aos príncipes cristãos, e até louvável, baptizar essas crianças, mesmo contra a vontade dos próprios pais infiéis, desde que estes sejam seus súbditos, se proceda com a devida precaução de modo a não sofrerem qualquer dano grave e futuramente se lhes proporcione uma cuidada educação religiosa $\left({ }^{38}\right)$.

E evidente que se trata da administração do baptismo por ordem duma autoridade pública que tenha verdadeiro poder sobre os pais e não de qualquer autoridade ou pessoa privada $\left({ }^{37}\right)$. E neste sentido o Doutor Subtil vai ainda mais longe ao afirmar que até os próprios pais infiéis podem ser obrigados com ameaças e terror a receber o baptismo e a conservá-lo depois de recebido, pois seria um bem muito

(34) Como introdução a toda esta temática orientaram-nos os importantes trabalhos de Teófilo Urdanoz, O.P. «Tratados de la fe y de la Esperanza», in Suma Teologica de Santo Tomas de Aquino, BAC, Madrid, 1959, pp. 340-389 e Venancio D. Carro, O.P., La teologia $y$ los teologos - juristas españoles ante la conquista lie America, Tomos I e II, Madrid, 1944.

(35) Cf. J. Duns Escoto, in IV Sent. Dist. IV. q. IX.

(3e) Idem, Dist. IV. q. IX, n. 1 e 2.

(37) Idem, Dist. IV. q. IX, n. 1. 
maior cumprir assim o preceito, do que observar livremente a lei e não o receber $\left({ }^{38}\right)$.

Escoto fundamenta a sua teoria no princípio do poder e do domínio absoluto de Deus ao qual todos os outros domínios inferiores se devem submeter. Ora sobre as crianças, Deus tem um maior direito do domínio do que os próprios pais e na ordem universal todos os poderes estão ordenados, de tal modo que um poder inferior não obriga naquelas coisas que estão contra um poder superior, argumentação, que resume, propriamente, na célebre frase de S. Agostinho: «Se um poder te ordenar alguma coisa que não deves fazer, então despreza absolutamente esse poder, temendo um poder maior». E esolarece com o exemplo do curator em relação ao Proconsul, do Proconsul ao Imperador e do Imperador a Deus $\left.{ }^{(39}\right)$.

Tomás de Aquino, examinando precisamente esta questão, se se devem baptizar os filhos dos judeus ou dos outros infiéis, sem o consentimento dos pais, responde que é contra o que está no Decreto de Graciano e no IV Concílio de Toledo que determina: de futuro, ninguém pode ser obrigado a crer, pois a salvação não pode ser forçada, mas voluntária, a fim de que se cumpra a justiça em toda a sua integridade $\left({ }^{40}\right)$.

Porque os filhos dos infiéis ou têm o uso da razão ou não. Se possuem o uso da razão, então são senhores dos seus actos no que respeita ao direito natural e divino e portanto podem, se essa for a sua vontade, receber validamente o baptismo, assim como o matrimónio, mesmo que os seus pais se oponham $\left({ }^{41}\right)$.

Neste caso podem ser conduzidos à fé, não por coacção, mas por persuasão, a fim de que possam crer livremente e receber o sacramento $\left({ }^{42}\right)$.

Mas se, pelo contrário, ainda não têm o uso da razão, então, encontram-se, segundo o direito natural, sob a tutela dos seus pais, até poderem cuidar de si próprios. Por isso, se diz que os filhos dos antepassados "se salvaram pela fé dos pais» $\left.{ }^{(43}\right)$. Neste caso seria ofender a justiça natural se se baptizassem contra a vontade dos seus pais, como igual-

(38) Idem, Dist. IV. q. IX. n. 2 e 3.

(39) Idem, Dist. IV. q. IX. n. 1.

(40) STh. III, q. 68 a. 10.

(41) STh. III, q. 68. a. 10.

(42) Cf. STh- II-II, q. 10, a. 12; III, q. 68,a 10.

(43) Cf. STh. III,q . 68, a. 10; II-II, q. 10, a. 12. 
mente seria um atentado à justiça baptizar contra a própria vontade os que já tiveram o uso da razão $\left({ }^{(4)}\right)$.

Primeiro, porque seria perigoso baptizar os filhos dos infiéis, em tais circunstâncias, já que facilmente voltariam à infidelidade, dado o natural afecto aos seus pais, pois quando chegassem a uma idade mais perfeita poderiam ser induzidos por eles a abandonar aquilo que receberam sem conhecerem, o que redundaria em detrimento da fé $\left({ }^{45}\right)$. Em segundo lugar porque se opõe à justiça natural.

De facto, o filho, é naturalmente algo do pai, de tal modo que no começo da sua vida, quando se acha no ventre da sua mãe, não se distingue corporalmente dos seus próprios pais. E mesmo depois de sair do útero materno, ainda continua sob o cuidado dos seus pais, antes do uso do seu livre arbítrio como se permanecesse num certo seio espiritual e em tal situação não difere do animal irracional. Pois assim como o boi ou o cavalo é propriedade de alguém podendo segundo o direito civil, usar dela como entender, como instrumento próprio, assim também por direito natural o filho antes do uso da razão está sob a protecção dos seus pais. Por isso seria contra a justiça natural subtrair a criança, antes do uso da razão, do cuidado dos seus pais ou determinar algo sobre ele contra a vontade dos mesmos $\left({ }^{48}\right)$.

E referindo-se ${ }_{z}$ noutro passo, aos que apelam para a autoridade de alguns doutores católicos, argumenta que a Igreja nunca teve por costume baptizar os filhos dos judeus contra a própria vontade dos pais e que esta tradição é a única autoridade que em tudo deve ser seguida. Porque a própria doutrina dos Doutores só recebe a sua autoridade da Igreja. Por isso, deve estar-se mais atento à autoridade da Igreja do que à de $\mathrm{S}$. Agostinho ou de $\mathrm{S}$. Jerónimo ou de qualquer outro Doutor. Ora, a Igreja, nunca teve por norma baptizar os filhos dos judeus contra a vontade dos pais, apesar de terem existido, em tempos remotos, muitos e poderosos príncipes católicos, como Constantino e Teodósio, que tiveram por conselheiros bispos muito dignos, como S. Silvestre e S. Ambrósio, respectivamente, que nunca deixariam de impetrar tal imposição aos imperadores, se estivesse conforme com a razão natural $\left({ }^{47}\right)$.

(44) Sth. III, q. 68 , a. 10.

(45) Cf. STh. III, q. 68, a. 10; II-II, q. 10, a. 12.

(48) STh. II-II, q. 10, a. 12.

(47) STh. II-II, q. 10, a. 12. 
Também contra os que afirmam que os judeus são escravos dos reis e dos príncipes e que estes podem, sem injúria, baptizar os filhos dos judeus, responde que de facto são escravos dos príncipes, segundo o direito civil, mas que este deixa intacto e não exclui a ordem do direito natural e divino $\left({ }^{48}\right)$.

E quase em género de conclusão, argumenta, por último, que o homem se ordena para Deus mediante a inteligência através da qual o pode conhecer. Mas a criança, antes do uso da razão, segundo a ordem natural, ordena-se para Deus através da inteligência dos pais, a cuja guarda está naturalmente confiada. Portanto, em relação às coisas de Deus em tudo se deve proceder consoante a disposição dos pais $\left({ }^{49}\right)$.

A resposta de Tomás de Aquino não podia ser outra, tanto mais que nos a. 8 e 10 tinha já lançado os seus fundamentos ao responder a duas questões prévias: se os infiéis podiam ser compelidos a abracar a fé e se os mesmos podiam exercer a autoridade ou domínio sobre os fiéis $\left({ }^{50}\right)$.

Enquanto Escoto seguiu uma posição voluntarista, exaltando e valorizando a ordem sobrenatural, a ponto de ofuscar ou subalternizar o direito natural, de tal maneira que os infiéis podiam ser forçados à conversão e a permitir o baptismo dos filhos, sob pena de perderem o direito natural sobre eles, Tomás de Aquino, curva-se perante os direitos humanos, na certeza de que não podia haver contradição entre o direito natural e divino, pois ambos, segundo ele, brotavam da mesma fonte, que era Deus.

Por isso, responde: os infiéis que nunca receberam a fé, como os gentios e os judeus, jamais poderão ser obrigados a crer porque o acto de fé é um acto essencialmente livre, isto é, da vontade. $\mathrm{E}$ todos os infiéis que exerciam a autoridade ou o domínio antes dos seus súbditos se converterem à fé, de modo nenhum perderão esse domínio e autoridade porque é um direito introduzido pelo direito humano e a distinção entre fiéis e infiéis pertence ao direito divino, fundado na graça, e este nunca pode anular um direito humano que se fundamenta na razão natural $\left(^{(51)}\right.$.

Estes princípios, enunciados, assim, por Tomás de Aquino, tiveram uma profunda repercussão e aplicação em
(48) Cf. STh. III, q. 68 a. 10; II-II, q. 10 , a. 12 , n. 3.
(49) Cf. STh. III, q. 68, a. 10, n. 3; II-II, q. 10, a. 12, n. 4.
${ }^{(50)}$ Cf. STh. II-II, q. 10 , a. 8 e 10 .
(51) Idem, a. 8 e 10 . 
toda a cristandade, principalmente na Península Ibérica, e não só nas relações dos cristãos com os mouros e judeus, mas sobretudo na solução dos grandes e novos problemas da evangelização, colonização e conquista da América.

Eles constituíram a grande base teológico-jurídica da insigne pléiade de teólogos, principalmente dominicanos, cujos nomes (como também dos seus opositores), ainda hoje ressoam nas escolas com admiração e veneração, em virtude do seu empenhamento na defesa dos direitos dos povos e da sua luta contra todo o abuso do poder fosse ele sagrado ou civil.

João de Paris (1240-1306), Ricardo de Middleton ( $† 1296)$, Guilherme Durando de São Porciano ( $\dagger 1334)$, Guido Terreni (1270-1342), João Paludano ( $† 1342)$, João Capréolo (†1444), João Torquemada (1383-1468), Cardeal Tomás de Vio Caietano (1468-1534), Francisco de Vitoria (1492-1545), Domingo de Soto (1495-1560), Bartolomé de las Casas (1474-1566), Melchor Cano (1509-1560), Juan de la Peña (†1565), Domingo Bañez (1528-1604), Martín Azpilcueta ou Doutor Navarro (1491-1586), Martín de Ledesma ( $₫ 1574)$, Luís de Molina (1535-1600) e posteriormente o célebre jesuíta Francisco Suárez (1548-1617), etc. $\left({ }^{52}\right)$, são alguns desses teólogos e juristas que seguiram e desenvolveram fielmente as teses do Doutor Angélico e as aplicaram tanto nas disputas entre o poder temporal e espiritual, como às novas situações surgidas com as descobertas dos novos mundos no respeito pela liberdade, direitos, bens e vidas, sobretudo dos povos nativos.

(52) Cf. Venancio D. Carro, ob. cit., Tomo I, pp. 431-442; Tomo II, pp. 50-52; 67-77; 137-144; 191-198; 226-230; 291-301. 